\title{
Effects of thyroxine treatment during lactation on the testicular function of rats across different ages
}

\author{
Souhila Dahmani-Said, Zohra Hamouli-Said, Assia Kamel, Fatima Hadj-Bekkouche
}

LBPO/Section Endocrinology, Faculty of Biological Sciences, USTHB, Algiers, Algeria

\begin{abstract}
Thyroid hormones are involved in the development of several tissues and organs and are essential for the normal growth and reproductive function. The aim of this study was to determine the effects of thyroid hormones on the development of testis and progression of spermatogenesis. Lactating mothers were treated with oral thyroxine (T4;20 $\mu \mathrm{g} / 100 \mathrm{~g}$ ) for 20 days after parturition. The pups were decapitated at the age of 20,40 and 60 days post partum. Neonatal hyperthyroidism resulted in a decrease in body and testis mass, an increase of free thyroxine and a decrease of testosterone concentrations in plasma of treated rats. The treatment was associated with a significant decrease of the diameter of seminiferous tubules and a slowdown in spermatogenesis, following a delay in the maturation of germ cells. We conclude that thyroid hormones affect the progression of postnatal spermatogenesis. (Folia Histochemica et Cytobiologica 2013, Vol. 51, No. 2, 107-114)
\end{abstract}

Key words: hyperthyroidism, testosterone, FT4, Sertoli cell, postnatal spermatogenesis, testis maturation, rat

\section{Introduction}

Among hormones secreted by the thyroid gland, thyroxine (T4) is the most abundant form, converted to the active hormone triiodothyronine (T3) by deiodinase enzymes (D1, D2 and D3). Several studies have demonstrated the effects of thyroid hormones (TH) on male gonads. It has been reported that hypothyroidism prolongs the proliferative phase of Sertoli cells and inhibits their differentiation, leading to a higher number of Sertoli cells, and in consequence to an increase in testicular size and sperm count at adulthood [1-4]. Treatment with propylthiouracil (PTU), an antithyroid drug, induced a maturation arrest of spermatogenesis, reduced the number of Leydig cells, decreased tubular diameter, caused interstitial edema and thickening of the basement membrane [5]. Thyroidectomy caused a reduction in the diameter of seminiferous tubules and their lumen, and led to degenerative changes in spermatogenic cells, which could have resulted from the inability of

Correspondence address: S. Dahmani-Said,

LBPO/Section Endocrinology, Faculty of Biological Sciences, USTHB, BP 32 El Alia, Bab-Ezzouar, 16111 Algiers, Algeria, e-mail: souhila.said@yahoo.fr
Sertoli cells to nurture germ cells [6]. Consequences of thyroidectomy on hormonal levels, including a reduction of GH and FSH blood levels have also been reported [6]. Conversely, short period of neonatal hyperthyroidism is associated with an increase in the size of testis and both Sertoli and germ cells number, reduced TSH levels, and a slight increase of blood FSH concentration [7, 8]. It seems that elevation of TH levels induces hypotrophy of fetal Leydig cells, and causes early differentiation of an increased number of mesenchymal cells into adult Leydig cells in prepubertal rats [9]. Although many reports demonstrating the effects of TH deficiency or excess on testicular function are available in literature [10,11], little is known about the effects of an elevation of blood TH levels in lactating mothers on the maturation of male gonads in their offspring. This led us to investigate the effects of hyperthyroxinemia on the evolution of male gonadic function across different ages.

\section{Material and methods}

Animals. Female Wistar rats $(\mathrm{n}=14)$ were housed under conditions of controlled lighting (light on from 8:00 AM to $6: 00 \mathrm{PM})$ and temperature $\left(25 \pm 2{ }^{\circ} \mathrm{C}\right)$ and fed with 
commercial chow $(23.3 \%$ proteins, $9 \%$ lipids, $48 \%$ carbohydrates and $3 \%$ vitamin mineral complex) ad libitum. After mating, each female was placed in an individual cage with free access to water and food. After birth, the dams with their respective pups were divided in two groups of 7 lactating mothers each one. The treated group (T) of lactating dams (kept with their pups) received a dose of $20 \mathrm{mg} / 100 \mathrm{~g}$ body weight (BW) of thyroxine (sodium salt of levothyrox 'H03AA01' solution, SERB, Paris, France) in drinking water, for 20 days starting first day post partum (dpp), whereas the control group (C) of neonatal rats was kept with their dams which received tap water. The pups were followed up and weighted weekly until their sacrifice at the ages of 20 , 40 and $60 \mathrm{~d} p p$. The pups were weaned at $30 \mathrm{~d} p p$.

Hormone assays. Blood was collected from treated and control decapitated rats. Plasma was separated and kept at $-20^{\circ} \mathrm{C}$ until analyses. Plasma free thyroxin (FT4) and testosterone levels were measured in duplicate using the radio-immunoassay (RIA) method (IM1363 and IM1119 for thyroxin and testosterone, respectively; Immunotech SAS, Marseille, France).

Histological and morphometric analyses. The testes were fixed in Bouin-Hollande solution for 3 days and embedded in paraffin prior to histological and morphometric studies of seminiferous tubules. Five micrometers thick sections were stained by Masson's trichrome method. The slides were viewed and photographed using a Zeiss photomicroscope equipped with a Motic digital camera and an ocular grid. The average tubular and luminal diameters of seminiferous tubules were determined by measuring 45 randomly selected tubular cross-sections per group and age.

Statistical analysis. Data are expressed as mean \pm standard error of the mean (SEM). Groups were compared using Student's t-test, and values of $p<0.05$ were considered to be significantly different. Body and testis weights and tubular and luminal diameters were assumed to be normally distributed. To obtain a normal distribution, plasma hormone levels were transformed to logarithms.

\section{Results}

\section{Body mass}

At $7 \mathrm{~d} p p$, the average body weights of the two groups of pups were similar. From $14 \mathrm{~d} p p$, the body weight was significantly lower in pups which mothers were treated with thyroxine (experimental group) compared with age matched control groups until $35 \mathrm{~d} p p(60.42 \pm 0.88 \mathrm{~g} v s$. $73.69 \pm 2.93 \mathrm{~g} ; \mathrm{p}<0.001)$. Later, the body weight values were higher in treated groups, however, not significantly different from the control rats (Figure 1).

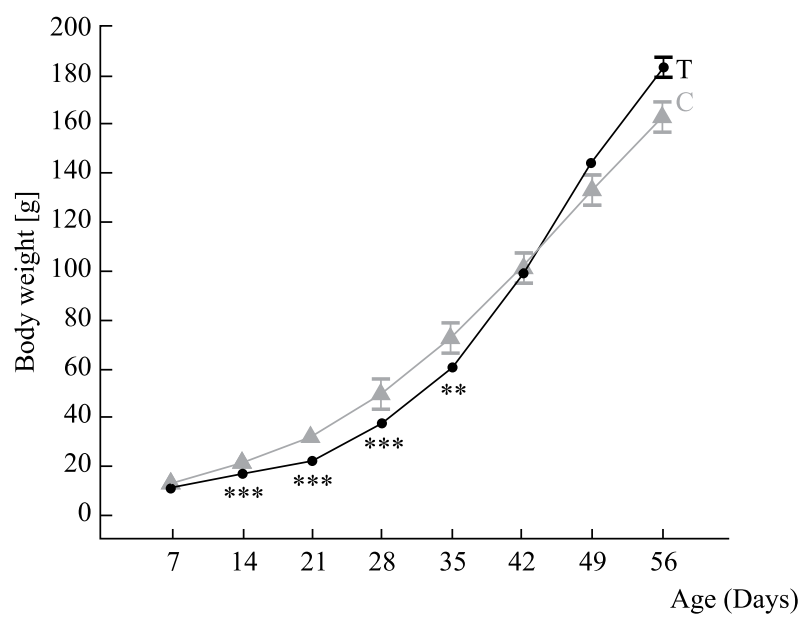

Figure 1. Body mass in control (C) and postnatal thyroxine treated $(\mathrm{T})$ rats. Bars represent mean $\pm \mathrm{SEM}$; treated $v s$. control: ${ }^{* *} \mathrm{p}<0.01,{ }^{* * *} \mathrm{p}<0.001 ; \mathrm{n} \geq 9$

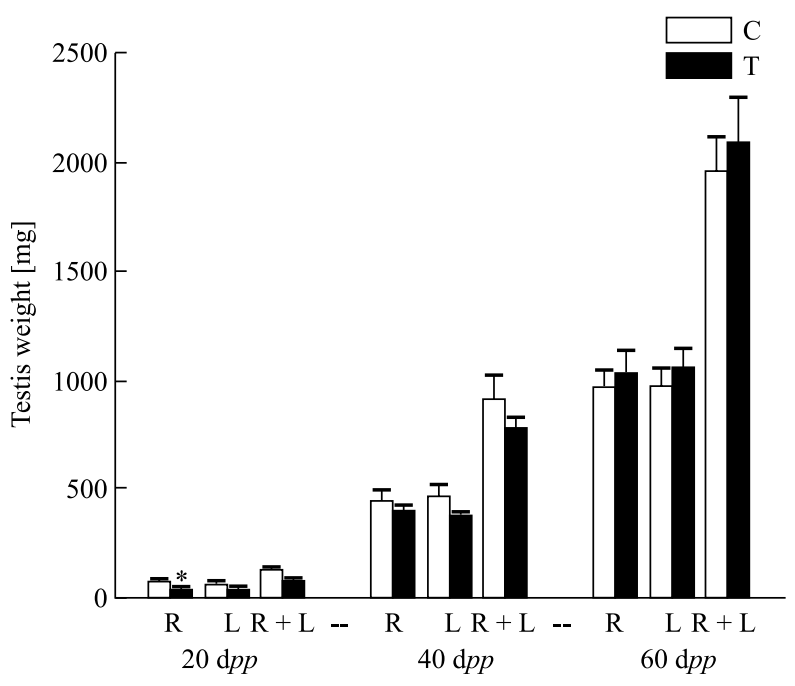

Figure 2. Testis mass in control $(\mathrm{C})$ and postnatal thyroxine treated (T) rats at 20, 40 or 60 days post partum (dpp). Bars represent mean \pm SEM; treated $v s$. control: *p $<0.05 ; \mathrm{R}$ — Right testis, L — Left testis; $\mathrm{n} \geq 5$

\section{Testis mass}

No difference was observed between the weight of the left testis and the right testis indicating absence of testicular dimorphism. During maturation (20 to $60 \mathrm{dpp}$ ), the testicular weight of control and treated rats increased gradually. At the age of 20 and 40 days, the mean testes weights of treated animals were lower than in control rats. Only right testes of 20-day-old treated group weighed significantly less than those of the control $(88.78 \pm 8.79 \mathrm{mg} v s .138 .40 \pm 18.47 \mathrm{mg}$; $\mathrm{p}$ $<0.05)$. At $60 \mathrm{~d} p p$, mean testes weights of treated rats were higher than those of control rats, however, the differences were not statistically significant (Figure 2). 


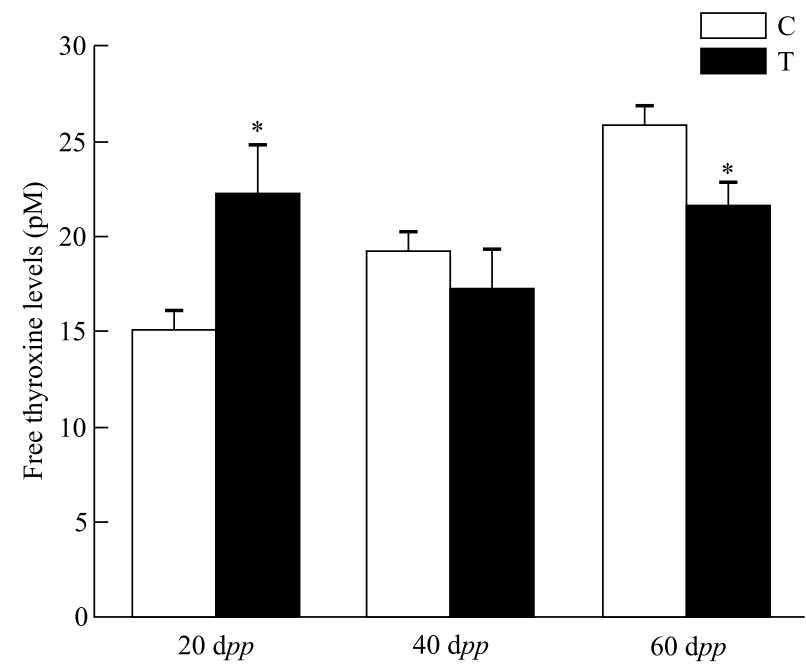

Figure 3. Plasma thyroxine concentrations in control (C) and postnatal thyroxine treated (T) rats at 20, 40 or 60 days post partum $(\mathrm{d} p p)$. Bars represent mean $\pm \mathrm{SEM}$; treated $v$ s. control: $* \mathrm{p}<0.05 ; \mathrm{n} \geq 5$

\section{Plasma hormone concentrations}

FT4 levels of control rats increased gradually in an age-dependent manner while FT4 levels of the treated group increased during 20 days of dams' $T 4$ treatment, were reduced 20 days later and increased again at 60 dpp. Plasma FT4 concentration on $20^{\text {th }}$ day in the treatment group was higher by $47.81 \%$ when compared with the mean value obtained in control group $(22.32 \pm 2.64 \mathrm{pM} v s .15 .10 \pm 1.12 \mathrm{pM}$, respectively; $\mathrm{p}<0.05)$. At 40 days FT4 levels were similar in both groups, and at 60 days, FT4 concentration was lower by $16.92 \%$ in treated than in control rats (not significant different) (Figure 3).

In control rats plasma testosterone levels increased gradually with age while in treated animals testosterone concentration increased slightly after $40 \mathrm{~d} p p$, yet remained lower than in controls. The level of testosterone was lower in treated than in control animals by $49.09 \%, 36.36 \%$ and $51.88 \%$ at 20,40 and $60 \mathrm{dpp}$, respectively, though at $60 \mathrm{~d} p p$ the difference did not reach statistical significance (Figure 4).

\section{Morphometric analysis}

The morphometric evaluation of testis structure revealed a reduced diameter of seminiferous tubules in treated 20-day-old rats as compared with control animals $(189.5 \pm 2.67 \mu \mathrm{m} v$ s. $220.69 \pm 3.13 \mu \mathrm{m}$, respectively, $\mathrm{p}<0.001)$ (Figure 5). In the treated 20-day-old rats, the lumen was reduced by $22.54 \%,(\mathrm{p}<0.05 \mathrm{vs}$. control) in some tubules and closed in others. The mean diameter of tubules of 40-day-old treated rats

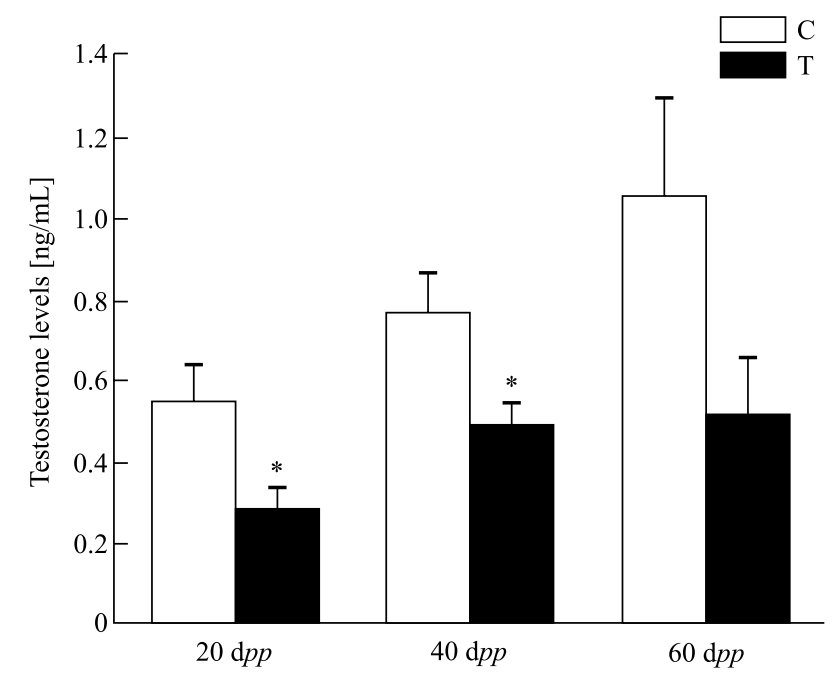

Figure 4. Plasma testosterone concentrations in control (C) and postnatal thyroxine treated (T) rats at 20,40 or 60 days post partum (dpp). Bars represent mean \pm SEM; treated vs. control: ${ }^{*} \mathrm{p}<0.05 ; \mathrm{n} \geq 5$

compared to control group was lower, and the mean diameter of tubule's lumen did not differ between treated and control groups. At $60 \mathrm{~d} p p$ the diameter of seminiferous tubules was higher by $6.19 \%$ and lumen diameter was higher by $14.82 \%$ in the treated group than in the control (Table 1).

\section{Testis morphology}

At the age of 20 days, spermatogonia and spermatocytes I were observed in the basal and adluminal areas, respectively, in control animals' testes. In treated rats, spermatogonia were frequently displaced from the basal area in those tubules which presented a lumen, while spermatocytes were condensed in the center of the tubules without well-defined lumen $\left(a_{1}\right.$, $b_{1}$; Figure 5). Spermatogenesis appeared to be slower in treated animals at $40 \mathrm{~d} p p$. The most advanced type of germ cell was spermatocyte II in treated animals, while the tubules of control animals contained some spermatozoa. These differences were absent in testes sections of 60-day-old rats since all the tubules contained spermatozoa, however, the seminiferous epithelium showed impaired germ cell development in T4 treated animals $\left(e_{1}, f_{1}\right.$; Figure 6).

\section{Discussion}

In this study, 20-day-old rats, breast-fed by lactating females who received Levothyrox, were hyperthyroid as compared to age-matched control pups. The increased FT4 level of the treated rats suggests that thyroid hormones were transferred to the pups with 

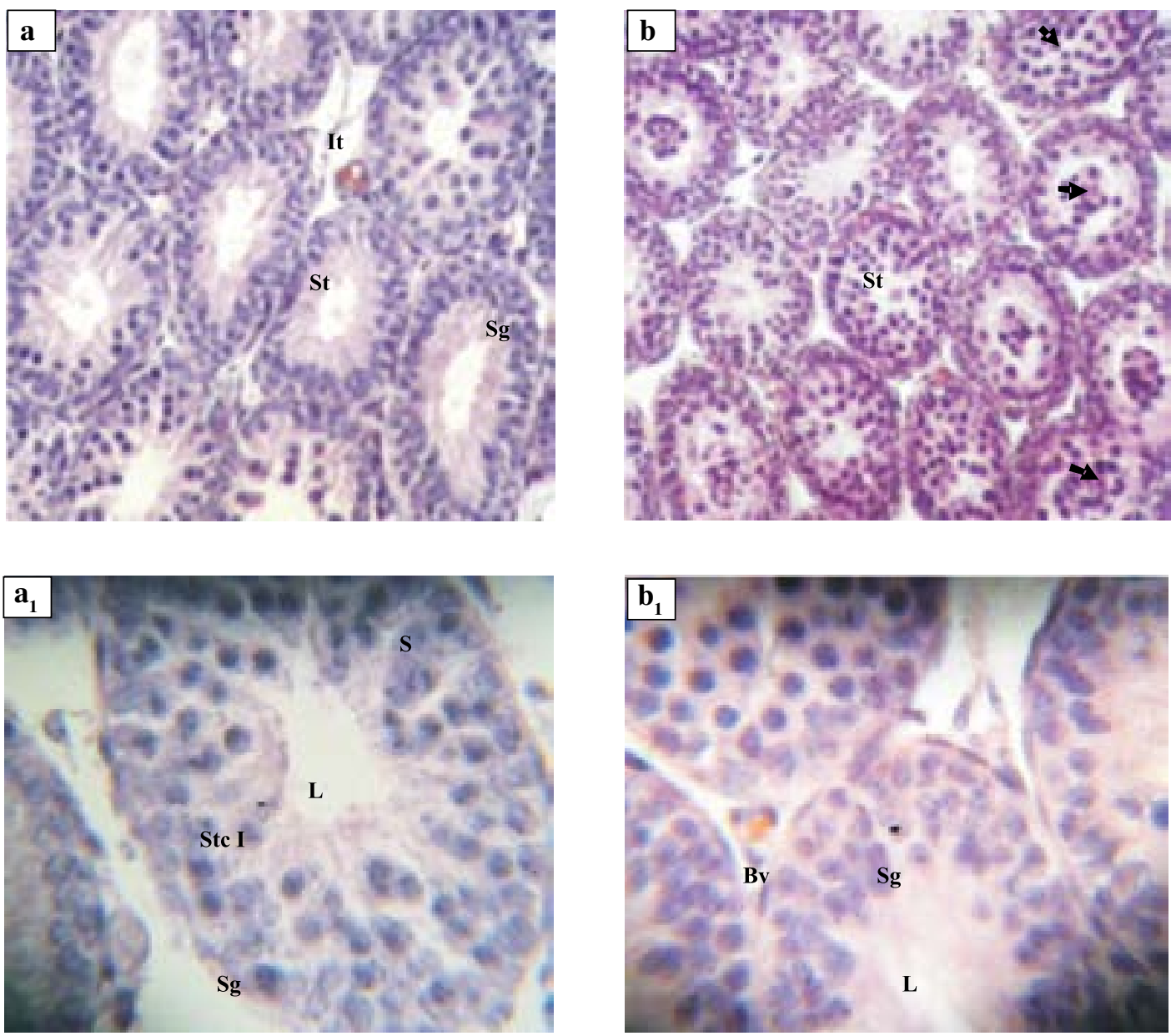

Figure 5. Testis sections in control $\left(a_{-}-a_{1}\right)$ and postnatal thyroxine treated $\left(b-b_{1}\right)$ 20-day-old rats. Bv: Blood vessel, It: Interstitial tissue, L: Lumen, S: Sertoli cell, Sct I: Spermatocyte I, Sg: Spermatogonium, St: Seminiferous tubule, arrows indicate closed seminiferous tubules. Total magnification: $\mathrm{a}-\mathrm{b}: \times 400, \mathrm{a}_{1}-\mathrm{b}_{1}: \times 1000$

Table 1. Diameters of the seminiferous tubule lumen in control (C) and postnatal thyroxine treated (T) rats at 20,40 or 60 days post partum (dpp)

\begin{tabular}{|c|c|c|c|c|c|c|}
\hline & \multicolumn{2}{|l|}{$20 \mathrm{~d} p p$} & \multicolumn{2}{|l|}{$40 \mathrm{~d} p p$} & \multicolumn{2}{|l|}{$60 \mathrm{~d} p p$} \\
\hline & \multicolumn{6}{|l|}{ Diameter (mm) } \\
\hline & Tubule & Lumen & Tubule & Lumen & Tubule & Lumen \\
\hline $\mathrm{C}$ & $220.69 \pm 3.13$ & $61.29 \pm 3.97$ & $323.48 \pm 10.63$ & $82.98 \pm 4.39$ & $486.79 \pm 9.21$ & $188.5 \pm 7.26$ \\
\hline $\mathrm{T}$ & $189.50 \pm 2.67$ & $47.47 \pm 4.48$ & $313.95 \pm 16.58$ & $100.97 \pm 8.76$ & $516.97 \pm 11.29$ & $216.45 \pm 8.18$ \\
\hline & $\mathrm{p}<0.001$ & $\mathrm{p}<0.05$ & $\mathrm{p}<0.05$ & $\mathrm{p}>0.05$ & $\mathrm{p}<0.05$ & $\mathrm{p}<0.05$ \\
\hline
\end{tabular}

Mean diameter was estimated from 3 round-shaped seminiferous tubules of 3 testis sections from 5 rats for each group

breast milk. At 40 dpp, FT4 concentration in treated rats was similar to the control group, which indicates a return to euthyroid state; however, thyroxine levels in 60-day-old treated rats were diminished, suggestive of lower thyroid activity. Similar results were obtained in rats after administration of exogenous T3 during the first five days post partum to achieve hyperthyroidism [12]. This treatment produced the expected immediate suppression of plasma T4 and TSH, with recovery toward normal values beginning within days of discontinuing the $\mathrm{T} 3$ regimen. Plasma T3 values were markedly elevated during the period in which T3 was administered, however, subsequently decreased with deficits persisting into young adulthood (50 d $p p$ ) [12]. As suggested by the authors, the future reactivity 

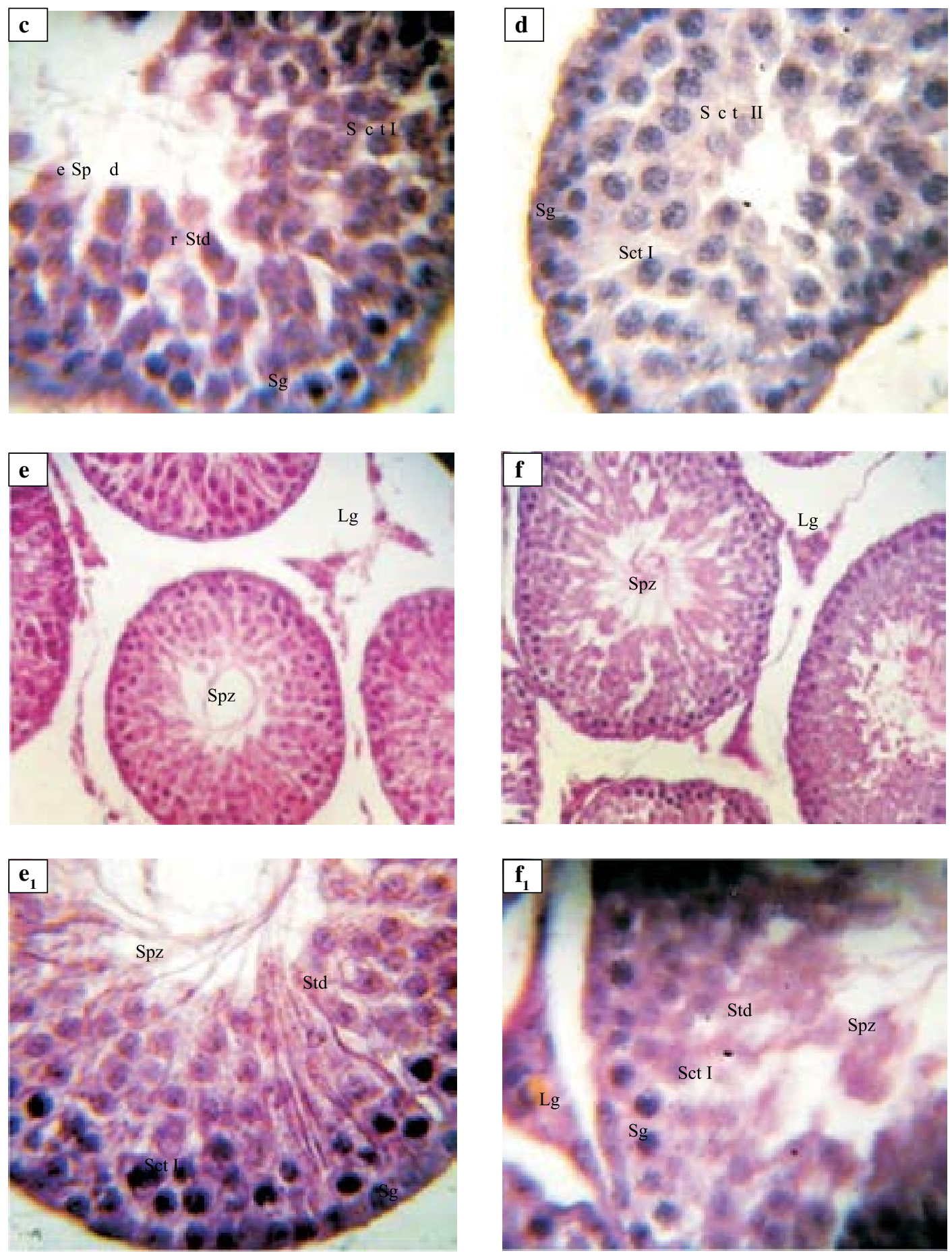

Figure 6. Testis sections in control (c and e-e $)$ and postnatal thyroxine treated (d and f- $\mathrm{f}_{1}$ ) 40- and 60-day-old rats. Lg: Leydig cell, Sg: Spermatogonium, SctI: Spermatocyte I, eStd: Elongated spermatide, rStd: Round spermatide. Total magnification: c-d: $\times 1000$, control and treated animals $40 \mathrm{~d} p p$, e-f: $\times 400$, control and treated animals $60 \mathrm{~d} p p, \mathrm{e}_{1}-\mathrm{f}_{1:} \times 1000$, control and treated animals $60 \mathrm{~d} p p$

to TSH seems to be determined during a critical period in which regulation of the pituitary-thyroid axis function is programmed by circulating thyroid hormones. Moreover, regulation of deiodinases' activities cannot be excluded [12].
According to the results of other authors $[9,13,14$, 15], hyperthyroidism induced by injection of thyroid hormones (T3: $50 \mu \mathrm{g} / \mathrm{kg} \mathrm{BW}, 80 \mu \mathrm{g} / \mathrm{kg} \mathrm{BW}, 100 \mu \mathrm{g} / \mathrm{kg}$ $\mathrm{BW}$ and T4: $50 \mu \mathrm{g} / 100 \mathrm{~g} \mathrm{BW}$, respectively) was associated with a significant body mass loss which could 
result from growth retardation resulting from imbalance of thyroid hormones and growth hormone. The reduction of body weight observed in treated rats can also result from an increase in circulating adiponectin $[16,17]$. Adiponectin increases insulin sensitivity by increasing fat oxidation resulting in a reduced body mass index [17] or a decrease in food intake of rats at weaning [15]. We did not observe any inflammation of the mammary glands in the mothers, or any behavior that could prevent pups from breastfeeding. The lower weight observed in treated rats could be caused by a potential decrease in lactation by affected mammary glands of hyperthyroid mothers, which has been reported by Palermo et al. [18]. However, lactation was not measured in our study.

In rat, Sertoli cell proliferation ceases by the age of 20 days [19-21]. The onset of spermatogenesis occurs around 5 days of age and mature spermatozoa are released into lumen of seminiferous tubuli at the age of 50 days [22]. Fetal type Leydig cells disappear soon after birth, during the first 2 weeks, and are replaced by adult type Leydig cells [23]. Immature adult Leydig cells are present at 21-28 dpp and have $40 \%$ of the testosterone secretory capacity of the mature adult Leydig cells which appear at 28-56 dpp [24]. In our study, testes weights, plasma FT4 and testosterone levels and testicular histomorphometry were performed at the age of 20 (pre-pubertal age), 40 (mid-pubertal age) and 60 days (post-pubertal age).

Testes weight was reduced in our 20-day-old treated rats. A similar reduction was reported for Sprague Dawley rats which received daily injections of T3 $(50 \mu \mathrm{g} / \mathrm{Kg} \mathrm{BW})$ for 21 days [9]. The average testes weights were not affected in T3 treated rats at days 5 and 7, however, were significantly smaller than in controls at days 9,12,16 and 21 [9]. This decrease can be explained by a reduction of the total seminiferous tubules' length per testis, due to early termination of Sertoli cells' proliferation under hyperthyroid conditions [25]. Sertoli cells play a key role in the initiation and maintenance of spermatogenesis [26] and are the first cell type known to differentiate within the fetal gonad [27, 28]. After birth, the immature Sertoli cells continue to proliferate until the beginning of puberty. At $15-20^{\text {th }}$ day after birth in rats, the cells stop dividing and start differentiating into their non-proliferative adult form [17, 18]. Sertoli cells provide growth factors and nutrients for developing germ cells. The effects of T3 on Sertoli cells' development are mainly exerted via TR $\alpha 1$ receptors [29, 30]. High neonatal triiodothyronine levels induce a reduction of Sertoli cells' proliferation rate, in vivo, in rats $[9,25]$ and boars [31] and in vitro [32]. The effect on germ cells' proliferation seems to depend on the duration of the treatment since short T3 administration was found to increase gonocyte differentiation, spermatogonia number, cell degeneration and proliferation at $6 \mathrm{~d} p p$, $\mathrm{T} 3$ transient administration increased spermatogonial development to adult values precociously (16 dpp) without affecting degeneration or proliferation, while continuous T3 administration increased cell degeneration and proliferation, but cell number was not affected [8]. Otherwise, mild hyperthyroidism induced in dams did not seem to affect Sertoli cell proliferation and differentiation in the offspring, rather a transient delay in the progression of spermatogenesis, at the time when plasma $\mathrm{T} 4$ levels were significantly elevated for the first time (15 dpp), was observed [33].

In addition to the negative effect on the progression of spermatogenesis and differentiation of Sertoli cells, as indicated by the reduced diameters of seminiferous tubules at 20 and 40 days as well as delayed tubule lumen formation, decreased levels of testosterone obtained in this study indicate a role of thyroid hormones for Leydig cell functions. Moreover, hyperthyroidism-associated alterations in the sex steroid hormones' metabolism, spermatogenesis and fertility, especially by affecting sperm motility, have been reported [34]. The presence of thyroid hormones' receptors TR $\alpha 1$ and TR $\alpha 2$ was demonstrated in immature and mature adult-type Leydig cells by Northern blot analysis [35] as well as using RT-PCR and immunohistochemistry [36]. According to Teerds et al. [37], thyroid hormones had a direct or indirect effect on the initiation of adult Leydig cells' formation in 12- and 16-day-old rats. These authors showed that the proliferative activity and the percentage of the Leydig cells in the T3-treated animals compared to the controls were increased at the ages of 12 and 16 days. At $16 \mathrm{~d} p p$, in the hyperthyroid animals, precursor cells were rapidly differentiating into adult-type Leydig cells and a significant reduction of plasma testosterone level was observed between controls and treated animals [37]. Their observations at the age of $16 \mathrm{~d} p p$ are important since we observed a significant diminution in plasma testosterone levels in our 20- and 40-day-old rats. Taken together, these results show that changes in neonatal-prepubertal thyroid hormone levels, directly or indirectly, influence the onset of the development of the adult-type Leydig cell population in the immature rat testis. While T3 induces acceleration of Sertoli cells' maturation [38, 39], testosterone and estradiol act with FSH to stimulate the Sertoli cells' activity and spermatogenesis [40, 41]. Estradiol and FSH act to prevent germ cells' apoptosis, stimulate spermatogonia differentiation and increase testosterone levels, while estradiol alone induces opposite effects [41, 42]. Synergic action 
of testosterone and FSH lead to maintain meiotic germ cells, and androgens are essential for the completion of meiosis [40, 43]. Decreased testosterone levels were probably associated with the slowdown of spermatogenesis observed in our study.

In order to induce hyperthyroidism in animals, mainly $\mathrm{T} 3$ has been used by other researchers [9, 12-14, 25, 37]. The daily T3 injection seems to cause a much more severe form of hyperthyroidism and lead to the acceleration of Sertoli cell and Leydig cell development as well as spermatogenesis $[9,14,25,37]$ while oral treatment of dams appears to be responsible for a transient delay of Leydig cell development and spermatogenesis in the offspring.

To our knowledge, there is only one previous study, which results are in agreement with ours, in which hyperthyroidism was induced by orally administered T4 in dams [33]. Differences between the results obtained with T3 and T4 can be due to 1) the fact that circulating $\mathrm{T} 4$ is present at higher levels and has a longer half-life than the active form T3 [44] and 2) the testis bioavailability of $\mathrm{T} 3$ which is determined by hormone transport across membranes and $\mathrm{T} 3$ inactivation by enzymatic deiodination $[45,46]$.

In conclusion, administration of $20 \mu \mathrm{g} / 100 \mathrm{~g} \mathrm{BW}$ thyroxine to lactating mothers resulted in a decrease of body and testis mass, plasma testosterone and altered testicular histomorphometry in pups. In regard to other studies, the observed effects seem to depend on the dose, administration route and duration of T4 treatment. Our results should be taken into account when assessing the risks of thyroxine treatment during lactation.

\section{References}

1. Cooke SP, Meissami E. Early hypothyroidism in rats causes increased sperm production in adult testis and reproductive organ size but does not change testosterone levels. Endocrinology. 1991;129:237-243.

2. Van Haaster LH, De Jong F, Docter R, De Rooij DG. The effect of hypothyroidism on Sertoli cell proliferation and differentiation and hormone levels during testicular development in the rat. Endocrinology. 1992;131:1574-1576.

3. Cooke PS, Kirby JD, Porcelli J. Increased testis growth and sperm production in adult rats following transient neonatal goitrogen treatment: optimisation of the propylthiouracil dose and effects of methimazole. J Reprod Fertil. 1993;97:493-499.

4. Hamouli-Said Z, Tahari F, Hamoudi F, Hadj-Bekkouche F. Comparative study of the effects of pre and post natal administration of a thyroid drug on testicular activity in adult rat. Folia Histochem Cytobiol. 2007;45:51-57.

5. Tahmaz L, Gokalp A, Kibar Y, Koçak I, Yalçin O,Ozercan Y. Effect of hypothyroidism on the testes in mature rats and treatment with levothyroxine and zinc. Andrologia. 2000;32:85-89.

6. Oncu M, Kavakli D, Gokcimen A, Gulle K, Orhan H, Karaoz E. Investigation on the histopathological effects of thyroid- ectomy on the seminiferous tubules of immature and adult rats. Urol Int. 2004;73:59-64.

7. Jannini EA, Ulisse S, Piersanti D et al. Early thyroid hormone treatment in rats increases testis size and germ cell number. Endocrinology. 1993;132:2726-2728.

8. Marchlewska K, Kula K, Walczak-Jedrzejowska R, Oszukowska E, Orkisz S, Slowikowska-Hilczer J. Triiodothyronine modulates initiation of spermatogenesis in rats depending on treatment timing and blood level of the hormone. Mol Cell Endocrinol. 2011;341:25-34.

9. Ariyaratne HB, Mendis-Handagama SM, Mason JI. Effects of tri-iodothyronine on testicular interstitial cells and androgen secretory capacity of the prepubertal rat. Biol Reprod. 2000;63:493-502.

10. Wagner MS, Wajner SM, Maia ALThe role of thyroid hormone in testicular development and function. $J$ Endocrinol. 2008;199:351-365.

11. Rajender S, Monica MG, Walter L, Agarwal A. Thyroid, spermatogenesis, and male infertility. Front Biosci E3. 2011;3:843-855.

12. Pracyk JB, Seidler FJ, McCook EC, Slotkin TA. Pituitary-thyroid axis reactivity to hyper- and hypothyroidism in the perinatal period : ontogeny of regulation and long-term programming of response. J Dev Physiol. 1992;18:105-109.

13. Zamoner A, Barreto KP, Filho DW et al. Hyperthyroidism in the developing rat testis is associated with oxidative stress and hyperphosphorylated vimentin accumulation. Mol Cell Endocrinol. 2007;267:116-126.

14. Rao JN, Liang JY, Chakraborti P, Feng P. Effect of thyroid hormone on the development and gene expression of hormone receptors in rat testes in vivo. J Endocrinol Invest. 2003;26:434-443.

15. Moura EG, Santos RS, Lisboa PC et al. Thyroid function and body weight programming by neonatal hyperthyroidism in rats -The role of leptin and deiodinase activities. Horm Metab Res. 2008:40:1-7.

16. Seifi S, Tabandeh MR, Nazifi S, Saeb M, Shirian S, Sarkoohi $P$. Regulation of adiponectin gene expression in adipose tissue by thyroid hormones. J Physiol Biochem. 2012;68:193-203.

17. Iglersias $P$, Diez JJ. Influence of thyroid dysfunction on serum concentrations of adipocytokines. Cytokine. 2007;40:61-70.

18. Varas SM, Munoz EM, Hapon MB, Aguilera Merlo CI, Gimenez MS, Jahn GA. Hyperthyroidism and production of precocious involution in the mammary glands of lactation rats. Reproduction. 2002;124:691-702.

19. Orth JM. Proliferation of Sertoli cells in fetal and postnatal rats: a quantitative autoradiographic study. Anat Rec. 1982;203:485-492.

20. Palmero S, De marchis M, Gallo G, Fugassa E. Thyroid hormone affects the development of Sertoli cell function in the rat. J Endocrinol. 1989;123:105-111.

21. Palmero S, Prati M, Bolla F, Fugassa E. Tri-iodothyronine directly affects rat Sertoli proliferation and differentiation. J Endocrinol. 1995;145:355-362.

22. Clausen OPF, Purvis K, Hansson V. Endocrine correlates of meiosis in the male rat. Arch Androl. 1979;2:59-66

23. Tapanainen J, Kuopio T, Pelliniemi LJ, Huhtaniemi I. Rat testicular endogenous steroids and number of Leydig cells between the fetal period and sexual maturity. Biol Reprod.1984;31:1027-1035.

24. Mendis-Handagama SM, Ariyaratne HB. Differentiation of the adult Leydig cell population in the postnatal testis. Biol Reprod. 2001;65:660-671.

25. Van Haaster LH, de Jong FH, Docter R, de Rooij DG. High neonatal triiodothyronine levels reduce the period of Sertoli 
cell proliferation and accelerate tubular lumen formation in the rat testis, and increase serum inhibin levels. Endocrinology. 1993;133:755-760.

26. Sharpe RM. Regulation of spermatogenesis. In: Knobil E, Neil JD (ed.). The Physiology of Reproduction. New York, Raven Press;1994:1363-1434.

27. Mackay S. Gonadal development in mammals at the cellular and molecular levels. Int Rev Cytol. 2000;200:47-99.

28. Brennan J,Capel B. One tissue, two fates: molecular genetic events that underlie testis versus ovary development. Nat Rev Genet. 2004;5:509-521.

29. Jannini EA, Carosa E, Rucci N, Screponi E, D'Armiento $\mathrm{M}$. Ontogeny and regulation of variant thyroid hormone receptor isoforms in developing rat testis. J Endocrinol Invest. 1999;22:843-848.

30. Holsberger DR, Kiesewetter SE, Cooke PS. Regulation of neonatal Sertoli cell development by thyroid hormone receptor alpha 1. Biol Reprod. 2005;73:396-403.

31. McCoard SA, Wise TH, Ford JJ. Endocrine and molecular influences on testicular development in Meichan and White composite boars. J Endocrinol. 2003;178:405-416.

32. Buzzard JJ, Wreford NG, Morrison JR Thyroid hormone, retinoic acid, and testosterone suppress proliferation and induce markers of differentiation in cultured rat sertoli cells. Endocrinology. 2003;144:3722-3731.

33. Rijntjes E, Wientjes AT, SwartsHj, de Rooij DG, Teerds KJ. Dietary-induced hyperthyroidism marginally affects neonatal testicular development. J Androl. 2008;29:643-653.

34. Krassas GE, Pontikides N. Male reproductive function in relation with thyroid alterations. Best Pract Res Clin Endocrinol Metab. 2004;18:183-195.

35. Hardy MP, Sharma RS, Arambepola NK et al. Increased proliferation of Leydig cells induced by neonatal hypothyroidism in the rat. J Androl. 1996;17:231-238.

36. Buzzard JJ, Morrison JR, O'Bryan MK, Song Q, Wreford NG. Developmental expression of thyroid hormone receptors in the rat testis. Biol Reprod. 2000;62:664-669.

37. Teerds KJ, De Rooij DG, De Jong FH, Van Haaster LH. Development of the adult-type Leydig cell population in the rat is affected by neonatal thyroid hormone levels. Biol Reprod. 1998;59:344-350.

38. Auharek SA, De França LR. Postnatal testis development, Sertoli cell proliferation and number of different spermatogonial types in $\mathrm{C} 57 \mathrm{BL} / 6 \mathrm{~J}$ mice made transiently hypo- and hyperthyroidic during the neonatal period.J Anat. 2010;216:577-588.

39. Singh R, Hamada A J, Agarwal A. Thyroid hormones in male reproduction and fertility. Open Reprod Sci J. 2011;3:98-104.

40. O’Shaughnessy PJ, Morris ID, Huhtaniemi I, Baker PJ, Abel MH. Role of androgen and gonadotrophins in the development and function of the Sertoli cells and Leydig cells: data from mutant and genetically modified mice. Mol Cell Endocrinol. 2008;306:2-8.

41. Walczak-Jedrzejowska R, Slowikowska-Hilczer J, Marchlewsk K, Oszukowska E, Kula K. During seminiferous tubule maturation testosterone and synergistic action of FSH with estradiol support germ cell survival while estradiol alone has pro-apoptotic effect. Folia Histochem Cytobiol. 2007;45 Suppl. 1:S59-64.

42. Kula K, Walczak-Jedrzejowska R, Słowikowska-Hilczer J, Oszukowska E. Estradiol enhances the stimulatory effect of FSH on testicular maturation and contributes to precocious initiation of spermatogenesis. Mol Cell Endocrinol. 2001;178:89-97.

43. Walczak-Jedrzejowska R, Slowikowska-Hilczer J, Marchlewska K, Kula K. Maturation, proliferation and apoptosis of seminal tubule cells at puberty after administration of estradiol, follicle stimulating hormone or both. Asian J Androl. 2008;10:585-592.

44. Chopra IJ, Sabatino L. Nature and sources of circulating thyroid hormones. In: Braverman LE, Utiger RD, ed. The Thyroid. Philadelphia, Lippincott Williams \& Wilkins; 2000:121-135.

45. Leonard JL, Visser TJ. Biochemistry of deiodination. In: Hennemann G, ed. Thyroid Hormone Metabolism. Marcel Dekker, New York; 1986:189-229.

46. Bates JM, St Germain DL, Galton VA. Expression profiles of the three iodothyronine deiodinases, D1, D2, and D3, in the developing rat. Endocrinology. 1999;140:844-851.

Submitted: 5 June, 2012

Accepted after reviews: 8 February, 2013 